\title{
Fermentation of sugar cane juice (Sacharum officinarum) cultivar RB 7515 by wild yeasts resistant to UVC
}

\author{
Viviane dos Santos Sobrinho ${ }^{1}$, Valéria Cristina Ferreira da Silva ${ }^{2}$ and Marney Pascoli \\ Cereda $^{1 *}$ \\ ${ }^{1}$ CeTeAgro - Centro de Tecnologia e Análise do Agronegócio, Instituto São Vicente. ${ }^{2}$ Programa Biotecnologia \\ Universidade Católica de Campo Grande - UCDB; 79117-900; Campo Grande - MS - Brasil.
}

\begin{abstract}
Commercial alcoholic fermentations coexist with microbial contamination come together with sugar cane or industrial water. The contaminants are bacteria or wild yeast that also results reduction in yield. The contaminants control use acid treatment and antibiotics. Disinfection by ultraviolet radiation is efficient in transparent liquid and has as advantage leaving no residues. Reports on the UV effect over microorganisms in turbid and colored liquids are scarce. The research evaluated the use of commercial UVC lamp in continuous reactor for reducing microbial load and its effect on the fermentation of sugarcane cultivar RB 7515. The sugar cane juice and tap water used in dilution were both exposed to doses of 0, 500, 1000, 2000 and 4000 Joules/l juice. The counts were made in specific culture media. The dose 500 Joules/liter was enough to eliminate the coliforms, but survived yeast and bacteria without difference to the others dose. The treated sugar cane juice was diluted to 12 Brix and fermented by the surviving wild yeasts until Brix stabilization. The alcoholic graduation was $5^{\circ}$ GL for all the treatment. It was proved the ability of wild yeasts resistant to UVC even with long fermentation times.
\end{abstract}

Key words: Alcoholic fermentation, contamination control, water, dilution, Wild yeasts, UVC resistance

\section{INTRODUCTION}

The alcoholic fermentation is a biochemical reaction where yeast transforms sugars (glucose and fructose) from the worth into ethanol, $\mathrm{CO}_{2}$ and energy stored as ATP.

In the Brazilian distilleries the fermentation time varies from 12 to 24 hours. After fermentation, the fermented liquid named wine pass through a sequence of distillation columns, separating water from ethanol. Hydrated alcohol is graduate $96^{\circ} \mathrm{GL}$ and after anhydrous dehydration reaches $99.7^{\circ} \mathrm{GL}$ (Lima et al., 2001).

For Oliveira-Freguglia and Horii, (1998) the sugar cane juice obtained by grinding sugar cane stalk contains approximately 78 to $86 \%$ water, 10 to $20 \%$ sucrose, 1 to $2 \%$ reducing sugar, 0.3 to $0.5 \%$ ash and between 0.5 and $1.0 \%$ of nitrogen compounds. The $\mathrm{pH}$ of the sugar cane juice varies between 5.2 and 6.8 (Corazza et al., 2001).

The Brix variation in sugar cane juice is $14^{\circ}$ to 22 ${ }^{\circ}$, depending on the extraction process. The best sugar concentration for the sugar cane juice fermentation are from 14 to $16^{\circ}$ Brix. To achieve these values is necessary to dilute the raw juice with water. This water must have quality close to that of drinking water (Nogueira and Venturini Filho, 2005; Elia Neto, 2008).

The use of water is intense in industries that processing sugar cane. Water use in sugar manufacture (30 $\mathrm{m}^{3} /$ sugar cane stalk tone) is higher than in ethanol production $\left(15 \mathrm{~m}^{3} /\right.$ sugar cane stalk tone). In the mixed distilleries (sugar + alcohol) that are the most common in Brazil, only the production uses about $21 \mathrm{~m}^{3}$ of water by sugar cane stalk tone (Nogueira and Venturini Filho, 2005).

The temperature may directly influence the fermentation process, favoring the multiplication of bacteria and the flocculation phenomenon. Temperature above $35^{\circ} \mathrm{C}$ affects the performance of yeast, reduces its viability and makes the fermentation efficiency to decreases. The optimum temperature for yeast growth is 30 to $34^{\circ} \mathrm{C}$, but 32 to $36{ }^{\circ} \mathrm{C}$ is better for fermentation (Angelis, 1996).

Author for correspondence: cereda@ucdb.br 
Microorganisms as contaminants may occur since the sugar cane plantation until the distillery and contamination reflects in fermentation time and yields.

Contamination by microorganisms is a serious concern in the alcohol industry because of its great capacity of adaptation. The sugarcane juice and the worth are excellent substrates for the microorganisms growth because they are well adapted to the water activity, $\mathrm{pH}$, and nutrients and to high environments temperature of the distilleries.

According to Oliveira-Freguglia and Horii (1998), the contaminated raw mater and water without treatment used for dilute the sugar cane juice, combined with a bad antibiotic treatment, keeps in the fermentation process a large number of bacteria and the products of its metabolism.

Duncan and Colmer, (1964) founded coliform in sugar cane plant in all the growing season and reported that members of the genus Aerobacter comprise a portion of epiphytic micro flora of the plant. These studies showed a predominance of $A$. cloacae coliforms in the portions of the upper, middle and bottom of saplings of sugar cane plant, but the predominant type on leaf sheaths was $A$. aerogenes. The number of different coliform found in sugar cane juice was divided equally between A. aerogenes, A. cloacae and E. coli.

The microorganisms contamination of fermentation processes cause several problems such as consumption sugar, decrease the viability of yeast cells due to toxins excreted in the medium, flocculation of yeast that causes loss of yeast cells at the bottom of the vat or in the centrifuge and a reduction in industrial yield, gums bio formation, especially the dextran, that increases the viscosity of the worth. All are possible to cause operational problems at the industry. The increasing of the viscosity of the worth reduce the net volume of vats, causing overflows that require the use of anti-foam agents (Alcarde and Walder, 1997).

The sugar cane juice obtained from crushing of the cane stalk in the milling, mixed with the water used for removal of residual sugar (imbibed water) they are rich in sucrose and reducing sugar and needs be conveniently diluted in order to be subjected to fermentation. The concentrations of the worth in Brazilian distilleries are commonly expressed in Brix degrees. The sugar cane juice needs to be diluted between 15 and 25 Brix degrees, averaging 18 to $20^{\circ}$ Brix (Lima et al., 2001).

The water used for diluted the sugar cane juice is also an important source of infection by microbial contaminants.

The disinfection of drinking and pools water with ultraviolet radiation is widely used in European countries. This method is preferred to the chemical process because leaves no residue (Cereda and Vilpoux, 2008).

Results of prior research from (Cereda and Vilpoux, 2008) showed the feasibility of new models of continuous bioreactors of the UCV in various industrial sectors and that the reactor model and dosage of radiation also has an important role in the results.

Santos et al. (2009) evaluated the use of UVC radiation to disinfect water for dilution of sugarcane juice. Using a continuous reactor it was founded that UVC ( 235 to $280 \mathrm{~nm}$ ) doses from 1000 to 4000 Joules/l was enough to reduces $5 \mathrm{log}$ cycles of contaminants in water from industrial plant.

The use of UV lamps in the decontamination is reported as a very effective technique. The literature suggests that it is possible to have an efficient treatment of colored and muddy liquid, but there are few reports of UV radiation in distilleries.

Silva (2010) report the results of sugar cane juice treatment by UVC radiation. The raw sugar cane juice from cultivar BR-7515 was subjected to treatment with UVC lamp $(254.1 \mathrm{~nm})$ in a reactor equipped with a pump for continuous circulation (Latin America SUREPURE Purification Machines UVC, R1 Model), providing doses from 0 to 4000 Joules / 1 . Sugar cane had $21^{\circ}$ Brix and $\mathrm{pH}$ of 5.3, with a predominance of non-reducing sugars $(272.83 \mathrm{~g} / \mathrm{l})$ that may including sucrose, with average values of reducing sugars of 31.03 $\mathrm{g} / \mathrm{l}$, which may include glucose and fructose. These values provide profiles of sugar where the non-reducing sugars represent $85 \%$ of the total and reducing sugars $15 \%$. The raw sugar cane juice showed totals mesophilic aerobic counts of $10^{4}$ FCU $\mathrm{ml}$ and $10^{5} \mathrm{FCU} / \mathrm{ml}$ for the yeast. The total

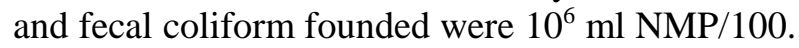
The reactor makes possible to eliminate the aerobic mesophiles at dosages above 250 Joules/l. However there was unexpected survival of organisms considered sensitive to ultraviolet radiation. The total and fecal coliforms showed the 
same survival curve profile of yeast cells, but coliforms bacteria were eliminated at doses greater than 1000 Joules per liter. With increasing radiation dose it was possible to observe an increase of no reducing sugars calculated as the difference between total reducing sugars and reducing sugars.

The objective of the research was to evaluate the effect of treatment with UVC on sugar cane juice and its fermentation by wild yeasts survivals.

\section{MATERIAL AND METHODS}

The experiment was conducted in June 2009 in the Center of Technology and Agribusiness Analysis (CeTeAgro), Catholic University of Campo Grande (UCDB), Mato Grosso do Sul, Brazil. The exact location is defined by the geographic coordinate's $20^{\circ} 26,34$ south latitude and $54^{\circ}$ $38^{\prime} 47$ west longitude, at 630 meters. The sugarcane juice was extracted from stalk of the second cut of cultivar RB-7515, collected manually. About 120 liters of cane juice was extracted in an electrical moving mill. The first 50 liters was discarding. Samples of raw sugar cane juice were taken aseptically for microbial and physic-chemical analysis.

A continuous reactor from "Surepure Latin America UVC Purification Machines Company" R2 Model was used treatment. It consisted of tanks and pumps mounted on a van that was available by all the time required to perform the experiment. The reactor had a battery of 10 lamps each one at $254.1 \mathrm{~nm}$ UVC spectrum, providing doses of 500, 1000, 2000 and 4000 Joules/liter. The sugar cane juice was circulated with the lamps out to provide the untreated control (0 Joules), and with the lighted lamps varying the exposure time to have the UVC doses. The treated raw sugar cane juice was than diluted with tap water previously sterilized under UVC (Cereda and Vilpoux, 2008) to provide sugar cane juice at $12^{\circ}$ Brix $(120 \mathrm{~g} / \mathrm{l})$ as worth. The Brix value of $12^{\circ}$ was selected slightly below the value of 14 to $16^{\circ}$ Brix recommended in literature (Venturini Filho and Nogueira, 2005) to ensure that the osmotic pressure was not an obstacle for fermentation.

Containers of 2 liters were previously fitted with hydraulic system that prevented the air to enter (air lock) during fermentation. Then they were sterilized under the $254.1 \mathrm{~nm}$ UVC light for 48 hours to ensure complete material sterilization.
Containers in triplicate received 1.5 liters of untreated (control) worth or treated with each dose of UVC and were placed at room conditions, monitored for temperature. In the period when the experiment was conducted at temperature ranged from the maximum of $27^{\circ} \mathrm{C}$ to the minimal $19^{\circ} \mathrm{C}$. Daily was also controlled the Brix value using refract meter Biobrix model 301. Samples of $50 \mathrm{ml}$ was enough for all analysis and it was previously established that samples would be collected even the worth reached values of 6,3 and $0^{\circ}$ Brix as established by (Colombo, 2009).

\section{Microbial Analysis}

The counts were obtained with appropriate samples submitted to decimal dilutions in containers with $90 \mathrm{ml}$ of distilled water previously sterilized by autoclaving ( $30 \mathrm{~min}$ to 120 pounds of pressure).

It was evaluated the total mesophilic aerobic bacteria by surface seeding technique using Nutrient Agar (standard) + Nystatin (500 mg / 1) counting in duplicate. For yeast counts was used Malt Extract + Ampicillin (500 mg / 1) in duplicate. The incubation was performed with plates inverted at $35^{\circ} \mathrm{C}$ for 48 hours (Silva et al., 2001; APHA, 2001).

The most probable number (MPN) is used for coliform counting in the multiple tube method, using sodium lauryl sulfate tryptose broth (LST). The incubation was performed at $35^{\circ} \mathrm{C}$ for $24-48$ hours (Silva et al., 2001; APHA, 2001). For all tubes have positive answer for gas production samples were seeded on corresponding agar plates containing the Eosin Methylene Blue medium and incubation performed at $35^{\circ} \mathrm{C}$ for 24 hours as described in APHA (2001) to detect fecal coliforms (thermo tolerant). Only the plates with a corresponding growth of colonies were counted.

\section{The fermentation evaluation}

The acidity and $\mathrm{pH}$ were carried out following the standard methodology described in the Handbook of Official Methods of the Institute Adolfo Lutz (2005). The Brix was reading with a Brix refract meter. Soluble carbohydrates were measured as reducing sugars (RS) by the method of SomogyiNelson (Nelson, 1994; Somogyi, 1945) with a Standard Curve adjusted with glucose and spectrophotometric reading at $535 \mathrm{~nm}$. The total reducing sugars (TRS) were also determined as reducing sugar by the same method after acid 
hydrolysis of complex carbohydrates as reported in (IAL, 2005). The non-reducing sugars, including sucrose, were evaluated by calculating the difference between ART and RT (ANR = ART-AR).

The alcohol content was determined by distillation and alcohol content determination by use an alcohol meter as described by Amerine and Ough (1976).

\section{RESULTS AND DISCUTION Characterization of the raw sugarcane juice cane}

The Brix can be used for the soluble sugars evaluation if considering that the value obtained less one unity (Brix-1) represents the amount of soluble sugars of the sugar cane juice (Corazza et al., 2001). The concentration of sugars in cane sugar is high. Although variable with the season, its average is from 15 to $20^{\circ}$ Brix (Smith and Inman-Bamber, 2005; Nogueira and Venturini 2005) states a variation in sugar cane juice Brix from $14^{\circ}$ to $22^{\circ}$ Brix.

The value obtained for the raw sugar cane juice was $20^{\circ}$ Brix that can be considered normal at this time of year. Silva (2010) found $25^{\circ}$ Brix for the same cultivar in May 2008 but as first harvest.

The profile of sugars from the sugar cane juice should present 10 to $20 \%$ sucrose and 1 and $2 \%$ reducing sugars (Silva et al., 2003; Oliveira and Horii, 1998). However the sugar cane juice analysis showed a profile with $126.00 \mathrm{~g} \mathrm{/} 1$ measured as reducing sugars (RS) and $98.00 \mathrm{~g} / 1$ as total reducing sugars (TRS). By calculation the non-reducing sugars were $28.00 \mathrm{~g} / \mathrm{l}$ as average. If compared to the expected profile it is necessary to consider that in the time of the analysis the raw sugar cane juice already had inversion of sucrose, with higher concentrations of RS in relation to NRS.

Silva (2010) was obtained in 2008 for the same cultivar, as first harvest, a profile of sugars closer to the raw cane juice as described by literature, where NRS represented $85 \%$ and RS $15 \%$ of total soluble sugars.

The crude cane sugar juice presented $\mathrm{pH} 3.7$, with $0.40 \mathrm{ml} \mathrm{NaOH} \mathrm{N} / 100 \mathrm{ml}$ acidity. The crude cane sugar juice was acid, if compared to the $\mathrm{pH}$ limits between 5.2 and 6.8 cited by Corazza et al. (2001). The results show that the raw sugar cane juice already presented a higher acidity and high reducing sugar content.

There is a paradigm to be considered because in Brazil the quality for sugar cane juice is only considered for sugarcane extraction. The figures founded in the literature are suitable for sugar production but for ethanol fermentation the acidity and simple sugars are suitable for alcohol fermentation by yeast.

In relation to microbial quality, Table 1 shows that the raw sugar cane juice without radiation treatment has a predominance of bacteria on yeast (1.5:1) but filamentous fungi (molds) are not founded. In commercial fermentation the worth should receive an addition of yeast as inoculum for increase the number of initial cells, making most rapid the fermentation and also reduce the growth of bacteria able to compete for the available sugars in the juice. Even so the number of yeasts found is quite close to the number considered as appropriate for the conduct of an alcoholic fermentation, which would be near $10^{9} \mathrm{CFU} / 1$. The yeast concentrations usually inoculated into the commercial alcoholic fermentation process is about $10^{8} \mathrm{CFU} / 1$ (Cereda and Garcia, 2008).

Table 1. Microbial analysis of raw sugar cane juice with Brix 20, $\mathrm{pH} 5.6$ (average of three replicates).

\begin{tabular}{ccccc}
\hline Doses & \multicolumn{2}{c}{$\mathbf{1 0}^{\mathbf{6}}$ UFC $/ \mathbf{l}$} & \multicolumn{2}{c}{ Coliforms $\left(\mathbf{1 0} \mathbf{~}^{\mathbf{N M P}} \mathbf{/ 1 0 0} \mathbf{~ m l}\right)$} \\
\hline Joule/liter & Yeasts & Mesophilic Aerobes & Total & Fecal \\
\hline 0 & 90.0 & 135.0 & 210.0 & 210.0 \\
500 & 6.3 & $-*-0$ & 0.0 & 0.0 \\
1000 & 2.7 & 71.0 & 0.0 & 0.0 \\
2000 & 9.0 & 26.0 & 0.0 & 0.0 \\
4000 & 9.0 & 9.0 & 0.0 & 0.0 \\
\hline
\end{tabular}

Legend: -*-: data lost by contamination

It was a surprise the presence of coliform bacteria, all classified as fecal coliform. The occurrence of coliform bacteria in raw sugar cane juice is rarely reported. According Andrieta et al. (2006) the 
sugar cane juice is rich in nutrients that favor the occurrence of groups of mesoplilic microorganisms, including the presence of coliform bacteria founded in samples from sugar and alcohol Brazilians industries.

The presence of coliform bacteria is explained by Duncan and Colmer, (1964) why they would be present on the plant sugar cane. The presence of total and fecal coliform in sugar cane juice of the same cultivar was also reported by Silva (2010).

Data in Table 1 shows that yeasts and mesophilic bacteria are both less sensitive to UV radiation but presented a sharp and constant reduction at all doses, but survival until the maximum dose evaluated. With respect to coliform (total and fecal) they were present only in the raw sugar cane juice (control).

The results was better that the results presented by Santos et al. (2009) that needed doses from 1000 to 4000 Joules/l UVC ( 235 to $280 \mathrm{~nm}$ ) to reduces $5 \mathrm{log}$ cycles of contaminants in water from industrial plant.

The initial charge for all groups was greater than that found by Silva (2010) that states the use of an older model reactor of the same Company, which provided less turbulence during the treatment of the sugar cane juice. The count founded by these authors was in the order of $10^{4} \mathrm{CFU}$ per ml. The sugarcane cultivar was the same as the methodology. The authors observed the survival of yeasts and mesophilic aerobic bacterial until the last dose (4000 Joules / 1) while no counts for fecal coliform have founded from dose of 4000 Joules / 1.

The reactor now used may be considered more efficient because the raw sugar cane juice submitted to treatment presented no longer count of microorganisms with 500 Joules / 1 dose. If is cconsidering the scores contained in Table 1 with the dose of 500 Joules $/ 1$ the treated sugar cane juice presented only aerobic mesophilic microbial contaminants and wild yeasts, both in order of $10^{6} \mathrm{UFC} / 1$.

The tap water treated with a dose of 4000 Joules per liter of UVC radiation was analyzed for its microbial quality and presented no counts for all groups of microorganisms.

\section{Monitoring of fermentation}

In Table 2 is possible to verify the performance of the fermentation, as function of the UVC dose.

Sugar cane juice treated with UVC radiation was dispersed in flasks and fermented with only the surviving micro flora. For the worth control the yeast count was $90.10^{6} \mathrm{CFU} / 1$, but in treated worth, considering all the doses, the average dropped to $7.0 .10^{6}$ yeast CFU / 1. Even considered the dilution of the raw sugar cane juice to adjust the Brix at 12, the total load of yeast would not change much relative to that number.

It was programmed to take samples for analysis each time the Brix fell to half in relation to the previous value. Thus it was scheduled for sampling Brix attenuated to 6.3 and 0 . The fermentation time was provided for 12 to 24 according to Lima et al. (2001). Table 2 shows that after 120 hours of fermentation, Brix had fallen by half, but in all the long of the fermentation never reached 3 or $0^{\circ}$ Brix.

Even with the prolongation of fermentation time corresponding to threefold of the 120 hours, little difference is founded in sugar's consumption content.

The longer fermentation time may be easily explained by the fact that there was no inoculation (addition of yeast), so fermentation occurred with the wild yeast. For this explanation points the fact that even in the control worth with tenfold the number of viable yeast cells, the profile was very similar.

The number of viable yeast cells in treated worth, although smaller, remained at the same level for all the dosages of UVC. The same scenario was observed for the proportion yeast/bacteria. Except for coliforms, they quantities remained quite stable. It was also must consider that the proportion of yeasts in relation to bacteria were similar for all doses, with a predominance of bacteria. The highest yeast rates occurred in the worth treated with dose of 500 and 1000 Joules/l. It was expected, therefore, differences in fermentation time and yield between the fermentation in relation to the treatment doses. 
Table 2. Parameters of wild yeast fermentation of sugarcane worth adjusted to Brix ${ }^{\circ} 12$ submitted to the treatment by ultraviolet radiation (average of three replicates).

\begin{tabular}{|c|c|c|c|c|c|c|}
\hline \multirow[b]{2}{*}{ Brix } & \multicolumn{3}{|c|}{ Acidity } & \multicolumn{3}{|c|}{ Sugar g/l } \\
\hline & Time $^{(*)}$ & Trititrable $^{(* *)}$ & pH & TRS & $\mathbf{R S}$ & NRS \\
\hline \multicolumn{7}{|c|}{ 0 Joules/I (witness) } \\
\hline 12 & 0 & 0.40 & 3.7 & 126.00 & 98.00 & 28.00 \\
\hline 6 & 120 & 1.60 & 3.2 & 41.00 & 40.00 & 1.00 \\
\hline 5 & 456 & 1.60 & 3.2 & 29.00 & 30.00 & 1.00 \\
\hline \multicolumn{7}{|c|}{500 Joules/l } \\
\hline 12 & 0 & 0.70 & 3.7 & 138.00 & 116.00 & 22.00 \\
\hline 6 & 120 & 1.80 & 3.3 & 43.00 & 43.00 & 0.00 \\
\hline 5 & 456 & 2.30 & 3.0 & 22.00 & 21.00 & 1.00 \\
\hline \multicolumn{7}{|c|}{1000 Joules/l } \\
\hline 12 & 0 & 0.70 & 3.8 & 132.00 & 102.00 & 30.00 \\
\hline 6 & 120 & 1.40 & 3.2 & 42.00 & 40.00 & 2.00 \\
\hline 5 & 456 & 1.50 & 3.1 & 21.00 & 18.00 & 3.00 \\
\hline \multicolumn{7}{|c|}{2000 Joules/l } \\
\hline 12 & 0 & 0.50 & 3.7 & 118.00 & 106.00 & 12.00 \\
\hline 6 & 120 & 1.40 & 3.2 & 41.00 & 39.00 & 1.00 \\
\hline 5 & 456 & 1.30 & 3.3 & 32.00 & 27.00 & 5.00 \\
\hline \multicolumn{7}{|c|}{4000 Joules/I } \\
\hline 12 & 0 & 0.50 & 3.8 & 120.00 & 96.00 & 24.00 \\
\hline 6 & 120 & 1.60 & 3.2 & 41.00 & 40.00 & 1.00 \\
\hline 5 & 456 & 1.70 & 3.0 & 22.00 & 22.00 & 0.00 \\
\hline
\end{tabular}

Legend: ${ }^{(*)}$ : Fermentation time in hours; $\left({ }^{* *}\right): \mathrm{ml} \mathrm{NaOH} / 100 \mathrm{ml}$; RS: Reducing Sugar, TRS: Total Reducing Sugar; NRS: Non-reducing sugar (by calculation).

The Table 2 shows that although the fermentation takes longer, the parameters analyzed point to a normal fermentation pattern, with an increase of acidity and $\mathrm{pH}$ drop, both proportional to the fermentation time. The acidity average was 1.70 $\mathrm{NaOH} / 100 \mathrm{~g}$. Although it may be considered in a normal range, this value was greater than that reported by Silva (2010) under similar conditions, but using selected yeast inoculation. In this case the average value was $0.40 \mathrm{NaOH} / 100 \mathrm{ml}$.

The analysis of reducing sugars (RS) and total reducing sugar (TRS) showed marked reduction of about $70 \%$, from Brix 12 to 6, with a less pronounced decline till Brix 5.0, which was the lowest value obtained. It is possible to say without much error that fermentation had nearly stabilized near 120 hours and the supplementary time brought small changes.

With a long fermentation time and the high residual Brix should expected a high residual sugar and low alcohol degree.
The fast reduction of NRS is expected because it includes sucrose, which is not fermentable by yeast, but after enzymatic transformation on RS (glucose and fructose) by the yeast invertase can be fermented into ethanol.

The Figure 1 shows the reduction of reducing (RS) and no reducing sugars (NRS) as function of radiation dose UVC to better characterize the profile of the consumption of sugars during fermentation. 


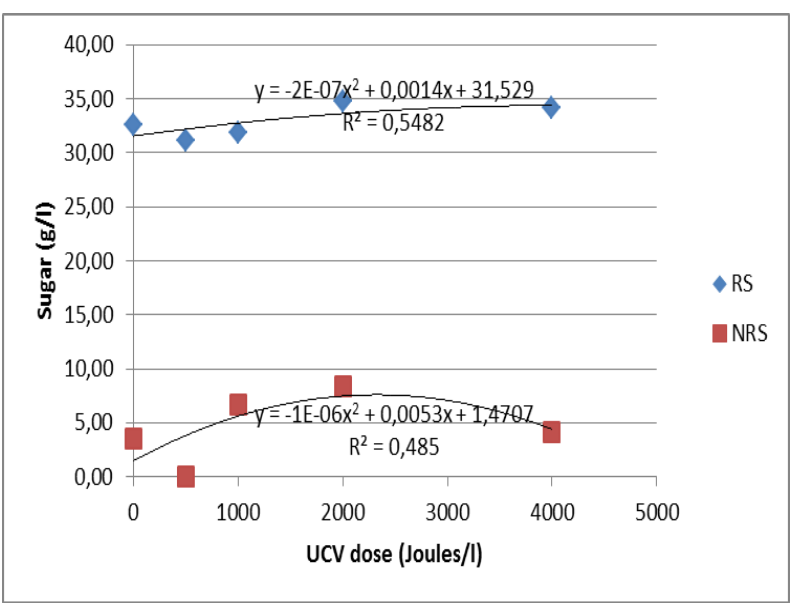

Figure 1- Profile of the percentage reducing sugars and no reducing sugars consumed in the fermentation by wild yeasts as a function of UVC dose.

The Figure 1showed the sugar consumption tended to increase with increasing dose of UVC for RS but remained some residual sugar. The RS consumed falls around $33 \%$ of the initial value of $120 \mathrm{~g} / 1$ for all the UVC radiation doses. The fall in sugar content can be best seen easy on NRS, and was therefore higher on the NRS that on RS. Despite these differences, the alcohol content obtained by distilling was $5^{\circ} \mathrm{GL}$ for all the treatments and the UVC radiation dose. This content is compatible with the amount of fermentable sugars in the worth. Even if the wild yeasts required longer times to ferment, what results in high acidity, the results were promising. Even that microbial contaminants was not completely eliminate, doses between 500 and 1000 Joules/liter did not significantly alter the composition of the sugar cane juice and provided the alcoholic yield expected.

\section{CONCLUSIONS}

In conditions where the experiment was conducted it was concluded that the UVC dose of 500 Joules per liter was effective to reduce the total and fecal coliforms (thermo tolerant) population present in the raw juice on about five logarithmic cycles $\left(10^{6}\right)$ not differing from the dose. The maximum efficiency in reducing microbial counts was observed between the doses 500 and 2000 Joules per liter with drops in counts of the numbers of colonies of bacteria (mesophiles) and yeasts. Still, fermentation conducted by wild yeasts with untreated sugar cane juice diluted with treated water, did not differ in time or yield of ethanol from the obtained with ultraviolet radiation dose of
500, 1000, 2000 and 4000 Joules per liter, although the reduction of contaminants have reached a decimal cycle. It was considered that the potentiality of wild yeasts resistant to UVC radiation was comproved.

\section{AKNOLEDMENTS}

To National Research Council (CNPq) PIBIC Program by the fellowships and Catholic University Dom Bosco by financial support.

To "Surepure Latin America UVC Purification Machines Company" based in São Paulo State by the use of UVC reactor and by the experience exchange on UCV

\section{RESUMO}

Fermentações alcoólicas comerciais convivem com contaminações por microrganismos presentes nos colmos de cana ou na água industrial. Os contaminantes são bactérias ou leveduras "selvagens" que resultam em prejuízos de rendimento. O controle destas contaminações é feito com ácido e antibiótico. A desinfecção por radiação ultravioleta é eficiente em líquidos transparentes e apresenta vantagem por não deixar resíduos. Relatos do efeito sobre microrganismos em líquidos turvos e coloridos são escassos. A pesquisa avaliou o uso de lâmpada comercial de radiação UVC para redução de carga microbiana e seu efeito sobre a fermentação do caldo de cana cultivar RB 7515. O caldo bruto e água usados na diluição a Brix 12,0 foram submetidos às doses de 0, 500, 1000, 2000 e 4000 Joules/l. As contagens foram feitas em meios de cultivo específicos. A dose 500 Joules/L foi suficiente para eliminar os coliformes, mas sobreviveram leveduras e bactérias mesófilas. Doses superiores a 500 Joules/1 eliminaram todos os microrganismos. $\mathrm{O}$ caldo tratado diluído a $12^{\circ}$ Brix foi fermentado com a leveduras sobrevivente até estabilização do Brix, proporcionando vinho a $5^{\circ} \mathrm{GL}$ para todos os tratamentos. Considerou-se que a potencialidade de leveduras selvagens resistentes à radiação UVC foi comprovada.

Palavras chave: Fermentação alcoólica, contaminantes, água, diluição, desinfecção

\section{REFERENCES}

Alcarde, A. R. and Walder J. M. M. (1997), Efeito da radiação gama na sobrevivência da levedura Saccharomyces cerevisiae (cepa M-300-A) em mosto de mel de cana-de-açúcar. Scientia Agricola, 54, 203-208.

Amerine, M. A. and Ough, C. S. (1976), Análisis de vinos y mostos. Zaragoza: Editora Acribia, $158 \mathrm{p}$. 
Andrietta, M. G. S.; Steckelberg, C.; Andrietta, S. R. (2006), Bioetanol - Brasil, 30 anos na vanguarda. Multi-Ciência: Revista Interdisciplinar dos Centros e Núcleos da UNICAMP, 7, 1-16.

Angelis, D. F. (1996), Agentes físicos, químicos e microbiológicos que afetam a fermentação etanólica. In: Ceccato, A. S. R. Guia prático de microbiologia. Araras: Universidade Federal de São Carlos, São Carlos, 1096.

APHA, American Public Health Association. (2001), Compendium of methods for the microbiological examination of foods. 4.Ed. Washington DC: 676p.

Cereda, M. P. and Vilpoux O. (2008), Uso de lâmpada ultravioleta GERMETEC para redução de conteúdo microbiano de amido comercial de mandioca. Versão Eletrônica. Available at: $<$ http://www.germetec.com.br/represe/red_conteud omicrobiano amido mandioca.pdf.> Consulted in 01 May 2008.

Colombo, P. Avaliação do efeito da radiação ultravioleta de lâmpada de média pressão sobre fermentação alcoólica de mosto de caldo de cana, inoculado com diferentes tipos de fermento, em duas temperaturas. Monografia (Pós-graduação Lato Senso) - Universidade Católica Dom Bosco, 2008.

Corazza, M. L.; Rodrigues, D.; Nozaki, G. J. (2001), Preparação e caracterização do vinho de laranja. Química Nova, 24, 449-452.

Duncan, C. L. and Colmer, A. R. (1964), Coliformes associated with sugarcane plants and juices. Applied Microbiology, 12, 173-177.

Elia Neto, A. (2008), Água na indústria de canade-açúcar. Workshop projetos PPP: Aspectos ambientais da cadeia do etanol de cana-de-açucar. São Paulo, Cetesb.

Garcia, D. P. R. e Cereda, M. P. Produção de mosto fermentescível de batata-doce (Ipomoea batatas) para produção de etanol. In: SIMPOSIO INTERNACIONAL DE BIOCOMBUSTÍVEL, 1; CONGRESSO BRASILEIRO DE AGROBIOENERGIA， 1., 2008, Uberlândia.
Anais...,Uberlândia: Universidade Federal de Uberlândia, 2008.

IAL, Instituto Adolfo Lutz. (2005), Métodos físico-químicos para análise de alimentos. 4.Ed. Brasília: Ministério da Saúde, 1018p.

Lima, U. A.; Basso, L. C.; Amorim, H. V. (2001), Produção de etanol. In: Lima, U. A.; Aquaron, E.; Borzani, W. and Schimidell, W. Biotecnologia industrial. São Paulo, Editora Edgard Blucher, p. $1-43$.

Nelson, N. A. (1944), Photometric adaptation of the Somogyi method for the determination of glucose. Journal of Biological Chemistry, 153, 375-80.

Nogueira, A. M. P. and Venturini Filho, W. G. (2005), Aguardente de cana. Botucatu: UNESP, $71 \mathrm{p}$.

Oliveira, F, R. M. and Horii, J. (1998), Cellular viability of Saccharomyces cerevisiae in mixed culture with Lactobacillus fermentum. Scientia Agricola, 55, 520-527.

Santos, W. R.; Luz, D. F.; Santos, L. C. R.; Tiburtino-Silva, L. A.; Cereda, M. P. (2009), Uso da lâmpada ultravioleta de média pressão para redução da carga microbiana na água industrial em usina de cana-de-açúcar. In: Congresso Brasileiro de Engenharia Agrícola. Campinas: Sociedade Brasileira de Engenharia Agrícola, 38, 150-160.

Silva, F. C.; Cesar, M. A. A.; Silva, C. A. B. (2003), Pequenas indústrias rurais de cana-deaçúcar: melado, rapadura e açúcar mascavo. Brasília: Embrapa Informação Tecnológica, 155p.

Silva, N.; Junqueira, V. C. A.; Silveira, N. F. A. (2001), Manual de métodos de análise microbiológica de alimentos. 2 Ed. São Paulo: Livraria Varela, 156 p.

Silva, V. C. Isolamento, avaliação e identificação de leveduras resistentes à Radiação Ultravioleta na planta e caldo de cana-de-açúcar. Dissertação (Mestrado em Biotecnologia) - Universidade Católica Dom Bosco, 2010. 
Smith, D. M. and Inman-Bamber, N. G. (2005), Water relations in sugarcane and response to water deficits. Field Crops Research, 92, 185-202.

Somogyi, M. (1945), Determination of blood sugar. Journal of Biological Chemistry, 160, 6973. 